\title{
Research on Business Model Innovation of Automobile Dealers from the Perspective of Value Creation
}

\author{
Yang Yuanze, Wang Xiuli* \\ School of Economics and Management, Hubei University of Automotive Technology, \\ Hubei province, Shiyan city, China, 442002
}

\begin{abstract}
The aim of this article is to study how the current era marketing environment affects the purchase behavior of car consumers and how to change the business model innovation of car Dealerships. In this paper, we first study the content of the business model of the automobile dealers through a literature survey and a field research, and analyze the reasons why car dealers implement business model innovation in the current era of the Internet, then proposes the suggestions for auto dealers on the innovation of business models, which is the innovation part of this article and will help to improve the competitiveness of auto dealers.
\end{abstract}

Keywords-Perspective of Value Creation; Automobile Dealer; Business Model Innovation; Path

\section{INTRODUCTION}

Automobile dealers are the most common type of the auto sales models currently in China, and their essence is the auto dealer model. Commonly car dealerships include 4S (Sale, Spare part, Survey, Service) stores, 3S stores (Sale, Spare part, Service), 1S stores (Sale or Service), and car supermarkets. The business model of car dealerships develops with the changes in their sales model which are constantly changing with changes in the socio-economic, technological, and industrial environments. The earliest form of the sales model is the "combined" mode of state-owned automobile operating companies in the era of planned economy. After the reform and opening, China's "agent" model of material trading companies was appeared by a result of economic restructuring, and gradually it also formed China's auto trading market in the mass production mode of the industrial era which become the most important sales model, and gradually developed into a factory direct sales or sales subsidiaries, brand monopoly $4 \mathrm{~S}$ shop model. Each change in the automotive marketing model reflects the game relationship between car manufacturers and the members of the downstream of the automotive industry chain, Such as automotive dealers and customers. For a long time, auto manufacturers are in the leading position of channel control rights, but under the background of the rapid development of the Internet, Variety in the way consumers collect information have brought about significant changes in the consumer purchasing decision process. The dealers have become more networked, larger-scale, regionalized, specialized, and diversified, and which is prompting dealers to innovate in business models.

\section{RESEARCH STATUS AT Home AND ABROAD}

In the past two decades, there have been more researches on business models in the theoretical and practical worlds. The research focuses on the concept, factors, classification, evolution, motivations, and business model innovation paths of the business model [1-2]. More emphasis is placed on the research of the business models of manufacturing companies and new energy auto companies or electric vehicle companies [3-4]. With the changes in the automotive market, automotive after-sales service companies have the necessity of business model transformation, and related research centers on the transformation of business models [5-7]. The objectives and implementation measures is focused on the current situation, classification and existing problems of business models of vehicle dealers. Related scholars proposed the business model innovation of automobile dealers from both macro-innovation and profitability innovation such as countermeasures and suggestions [8]. Another study focused on the business model of auto $4 \mathrm{~S}$ stores in the context of the Chinese automotive market, but more emphasis was placed on the research of the profit model of the $4 \mathrm{~S}$ stores [11]. Research on the new economic normality and the Internet environment is still relatively rare. Harvard Business School professor Clayton Christensen defines the concept of business model, that is, the business model is a system to create and transmit value [9]. Therefore, based on the concept of value creation proposed by this concept, this paper combines the characteristics of China's car dealers development to study the motivation, path and implementation strategy of the business model innovation of the car dealers under the background of Internet.

\section{The Content Of The Business Model Of ThE \\ Automobile DeAlers From the Perspective of VALUE CREATION}

Based on the perspective of value creation, the automobile dealers' business model is analyzed from three aspects: value proposition, value creation, and value acquisition.

Value proposition is the value that an enterprise provides to consumers through its products and services. The value proposition of car dealers needs to clarify two issues, namely, "who are our customers?" and "what products or services can we provide to customers?" The customers of the car dealers which are usually called "Target Customer Segments" are 
consumer groups that can be serviced by car dealers in the regional market and have certain common characteristics. The determination of target groups of car dealers is usually based on the market orientation of the manufacturer's brand and the characteristics of the regional market. The car dealers need to create value for the commonness of the target customers. This will inevitably require the car dealers to put the limited resources and conditions on the most valuable target customers. Automobile dealers usually sell a wide variety of vehicle models that are sold by the automakers, and each type of vehicle has a variety of configurations. The price, appearance, performance, and product attributes of the different configurations are all different. These different configuration models together constitute a car dealership product portfolio. For example: Shiyan Zhongwei Dongfeng Peugeot 4S shop sells Peugeot 307, 308, 301, 408, 508, 2008, 3008, 4008 and other cars, according to the characteristics and advantages of the above cars, combined with the local automotive consumer market characteristics, distinguished and defined from gender, age, family Life cycle period, family size, education level and social class, income level and expenditure pattern, occupational characteristics, industry background, lifestyle, personality characteristics, social customs, and so on, then extracted about potential targets with purchasing power customer's characteristics, such as the average price of 100,000 308 and the average price of 200,000 508, the target customers have greater differences in consumption, more accurately subdivided the regional brand target market for automotive brands. The car dealers can provide customers with products or services in three categories: First, The car dealers meet customer's basic car requirements by selling suitable automotive products to target customers, providing vehicle maintenance and spare parts supply services; second, it is the car dealers that satisfies the customer's emotional needs by providing value-added services. Third, it reflects the psychological demands of satisfying consumers through the unique business philosophy of $4 \mathrm{~S}$ stores in the business process.

Value creation is a process of business activities based on resources and conditions and also based on value allocation. The value distribution of car dealerships is the configuration of the resources and activities. The key point is that car dealers should do a good job of market positioning for each model and clarify who is the buyer, what are the advantages of the product, and how to sell the product to consumers and so on. The realization of car dealers' value allocation is usually achieved through smooth secondary distribution channels, a good network of partners, and continuous customer relationships. Core competencies are the lasting capabilities and qualifications that car dealers need to implement their business models that are not easily imitated and surpassed by other companies. The distribution channel is a variety of ways for car dealers to contact with customers. Specifically, how car dealers develop their regional markets, such as the distribution strategies of secondary outlets. The partner network mainly refers to the business alliances of car dealers. Car dealers often establish strategic alliances with partners such as banks, auto insurance companies, consulting companies, and logistics companies to share capital, customer data resources, and management services to enhance their competitiveness. Customer relationships are the links established between companies and their consumer groups. With the help of CRM software, car dealers' stores and customers to establish a good customer relationship, help to improve customer reputation and loyalty [10].

Value acquisition is the goal of the car dealer's business model, which is usually reflected in the profit model of car dealers, including the source of income and the cost structure. The source of income is the way for car dealers to create profits the cost structure is usually measured by the proportion of the various costs in the product cost, and the changes in the cost structure of car dealers reflect the ways and methods to save costs. Through the longitudinal comparison analysis of the cost structure in the car dealer's multi-year financial data and the horizontal comparison analysis with other car dealers of the same type, the car dealer's manager can understand much information such as the changing trend of the $4 \mathrm{~S}$ store's cost structure, how it compares with its competitors, and whether it can continue to decrease costs, etc.

\section{THE MOtIVATION OF CAR DEALERS TO IMPLEMENT BUSINESS MODEL INNOVATION AGAINST THE CURRENT ERA BACKGROUND}

The first reason is the change of the technological environment. Internet+ has become a characteristic of the times. The initial PC interconnection is turned to the Internet of Everything, mobile Internet, and high-speed interconnection. The Internet is accelerating the penetration and integration of traditional car dealerships, thus creating value and acquiring value is transformed. Second, the development of the Internet has brought e-commerce and online marketing. The resulting automotive network channels have had a huge impact on traditional physical channels. The third reason is the changes in the social environment. China has entered the era of mobile Internet, and information technology has penetrated into all stages of consumer buying behavior. These will create opportunities and challenges for the car dealer's business model (table 1). The Fourth is the changes in the economic environment. The biggest feature is the increase in purchasing power and consumption upgrades. Especially with the development of the automobile market, the owners of the 90's and the 70's and 80's owners are very different in the concept of consumption and purchase behavior. Fifth, the anti-monopoly law and the new automobile sales management methods have created important challenges for car dealers. 
TABLE I COMPARISON OF CONSUMER PURCHASE DECISION PROCESS BETWEEN TRADITION ECONOMIC EAR AND INTERNET EAR

Purchase
background

Consumers are more likely to be affected by $\mathrm{t}$ he business and generate purchases. This is $\mathrm{m}$ ainly reflected in the fact that once the consu mer has paid attention to the company in a cer tain way through the smart terminal, it will be affected by the company's subtle influence aft er a period of time, and thus creates a purchasi ng psychology.

Due to the portability of the mobile intelligent terminal, the information collection process is more convenient and timely. In addition, cons umer information gathering time is characteriz ed by "fragmentation", which requires compa nies to push appropriate information at the rig ht time and implement accurate marketing.

Due to the use of APP on mobile smart termin als, consumers will receive a variety of push a dvertisements, and consumers may choose fro $\mathrm{m}$ a variety of brand types.

Consumers' buying behavior occurs at any tim e and place, and consumers have higher dema nds on services.

Consumers tend to share through social media for each purchase. And no matter when and where consumers are, they can publish their o wn purchase and use experience, and can be a ccompanied by pictures, videos, etc.

\section{The Paths For The Business Model InNOVATION OF Auto DEALERS From THE PRESPECTIVE OF VALUE CREATION}

Changes in all elements of the business model will lead to business model innovation, and auto dealers can achieve business model innovation from three paths. The first is the change in the way of value creating. In the past, the value creation of auto dealers was to enhance the use value of products by increasing the functional configuration of products. Now it is necessary to strengthen the perception of product use value by emphasizing customer experience and provide integrated solutions from selling products to providing services. 
TABLE II CUSTOMERS' INCREASED VALUE WITH THE HELP OF CAR DEALERS

\begin{tabular}{|c|c|c|}
\hline No. & Features & Function description \\
\hline 1 & $\begin{array}{l}\text { Maintenance } \\
\text { reminder }\end{array}$ & Car dealers send maintenance reminder to the owner \\
\hline 2 & $\begin{array}{l}\text { Online } \\
\text { Reservations }\end{array}$ & Provide car owners with online booking maintenance \\
\hline 3 & $\begin{array}{l}\text { One-click } \\
\text { navigation }\end{array}$ & $\begin{array}{l}\text { (1) The car owner connects to the customer service staff via the "one- } \\
\text { touch call" button of the mobile client and informs the destination } \\
\text { (2) The customer service personnel downloads the inquired destination address to the mob } \\
\text { ile client through the mobile network. } \\
\text { (3) The mobile terminal implements automatic navigation according to the destination ad } \\
\text { dress, avoiding the manual operation of the owner }\end{array}$ \\
\hline 4 & $\begin{array}{l}\text { Roadside } \\
\text { assistance }\end{array}$ & $\begin{array}{l}\text { The car owner connects to the call center via a hotline to call for help. The customer servi } \\
\text { ce representative can respond to various emergency situations and contact the local emerg } \\
\text { ency assistance agencies such as the police, medical care, and fire protection so that the re } \\
\text { scue team can quickly reach the exact location of the owner. }\end{array}$ \\
\hline 5 & Illegal inquiry & $\begin{array}{l}\text { According to the license plate number to automatically and quickly check the violation of } \\
\text { the vehicle, to remind owners to avoid re-offense. }\end{array}$ \\
\hline 6 & $\begin{array}{l}\text { Parking space } \\
\text { sharing }\end{array}$ & Provide a parking space sharing platform for drivers \\
\hline 7 & Track sharing & $\begin{array}{l}\text { Drivers share features. For example, a driver can share his own driving trajectory at a } \\
\text { certain time with friends by using the track search function. }\end{array}$ \\
\hline 8 & $\begin{array}{l}\text { Points of } \\
\text { interest }\end{array}$ & $\begin{array}{l}\text { The owner connects to the call center customer service personnel through a hotline to inq } \\
\text { uire the location of the point of interest and related information such as } \\
\text { hotel, maintenance, gas stations, etc. }\end{array}$ \\
\hline 9 & Product display & $\begin{array}{l}\text { Car dealers pushes new models of the car, new discounts and other information to owners } \\
\text { through mobile phones }\end{array}$ \\
\hline 10 & $\begin{array}{l}\text { Used car } \\
\text { transactions }\end{array}$ & Provide a used car trading platform for divers \\
\hline 11 & $\begin{array}{l}\text { Cheyou } \\
\text { community }\end{array}$ & $\begin{array}{l}\text { Establish a SNS community for divers to meet the needs of friends and information sharin } \\
\mathrm{g}\end{array}$ \\
\hline 12 & $\begin{array}{l}\text { Business } \\
\text { alliance }\end{array}$ & $\begin{array}{l}\text { Business alliance applied in car wash, beauty, repair, maintenance, driver's behalf, } \\
\text { insurance, annual review, physical examination of car, etc. }\end{array}$ \\
\hline .... & ...... & ..... \\
\hline
\end{tabular}

The second is the change in value transfer process. From previous promotion and promotion, it has become a variety of information and services for customers, from single information transmission to two-way circulation. The most important thing is the development and use of auto dealers using APPs based on mobile phone terminals. App needs to achieve corresponding functions to meet customer demand for services.

The third is that the change in the way value is acquired. In the source of income, auto dealers was making money from customers in the past, and now they changed the way by helping customers make money; auto dealers can also reduce costs through cost structure reduction and asset structure lightening. In terms of income sources, using the "free" nature of internet thinking can create more "free modes" for car consumers, and use free and paid tactics flexibly according to the car's grade and the different needs of different customer segments. The free online and offline charge makes it easier to achieve a balance between attracting customers and making profits. Under normal circumstances, companies can provide basic services in the field of car maintenance free of charge, but charge premiums such as advanced or customized remodeling services, or other customer segmentation groups are willing to pay for cross-subsidization so that a diversified source of income can promote the robustness and profitability of auto dealers.

\section{CONCLUDING REMARKS}

Through the innovation of the business model, the profitability of auto dealers can be improved and the transformation and development of auto dealers can be realized. With the gradual increase of the discourse power of auto dealers in the industry chain, even under the dual influence of Internet+ and the new "Automotive Sales Management Measures", large-scale distributor groups is emerged. The innovation of their business model and the improvement of profitability will inevitably make large-scale dealer groups have developed into a platform business. Platform vendors will complete their goals by integrating global resources, building an automotive business ecosystem, which in turn promotes 
innovation in their business models and increases profitability. There is no limit to innovation, and auto dealers need to continuously innovate in business models in order to continuously improve their profitability and enhance and maintain their competitiveness.

\section{ACKNOWLEDGMENT}

This article was funded by the Innovation Project of Hubei University of Automotive Technology.

[Author] Yang Yuanze, School of Economics and Management, Hubei University of Automotive Technology, Marketing 161 student; Wang Xiuli (Corresponding Author), Associate Professor, School of Economics and Management, Hubei University of Automotive Technology.

\section{REFERENCES}

[1] Qiu Ting. Research on innovation of business model of auto manufacturers under internet thinking [D], Beijing Jiaotong University, 2016.6.

[2] Zhao Chuanxi. On the Remodeling of Business Model of Automobile Dealer Group [J], China Chief Accountant, 2014(9): 31-34.

[3] He Fang. The collective profit model of China's top 100 auto dealers is in urgent need of transformation. 21st Century Business Herald, 2011(6)

[4] Zhang Hao. Discussion on the business model of China's auto afterservice enterprises after China's accession to the WTO_-Based on the perspective of industrial chain analysis [J], International Business Studies, 2008(4):20-25.

[5] Luo Yu, Li Liangyu. Business Model Innovation in the Internet Age: A Perspective of Value Creation [J], China Industrial Economy, 2015(1): 95-106.

[6] YE Kai. O2O Practice: O2O Method of Internet+ Strategic Landing [M], Beijing: Machinery Industry Press, 2015.

[7] Tian Qingfeng, Zhang Yinyin, Yang Qing. Business Model Innovation: A Review of Theoretical Research Progress and Empirical Research [J], Management Modernization, 2018(1): 123-128.

[8] Han Longshi. Internet + Automotive New Thinking and Business Model Innovation [J], Business Management, 2015(7):104-106.

[9] Liu Shijin. Market Opening, Competition, and Industrial Progress: Controversies and Important Experiences in the 30-year Development of China's Automobile Industry [J]. Management World, 2008(12):1-9.

[10] Wang Xiuli. Channel Model Innovation for Special Purpose Vehicles: Taking Dongfeng Chuangpu Special Purpose Vehicle Company as an Example [J]. Reform and Strategy, 2015.8. 